\title{
Production and export potential of cricket powder in Costa Rica: an exploratory study
}

\author{
I.M. Bermúdez-Serrano ${ }^{1 *}$ iD , A.M Quirós ${ }^{2}$ and U. Dornberger ${ }^{1}$ \\ ${ }^{1}$ SEPT Competence Center, Leipzig University, Ritterstrasse 9-13, 04109 Leipzig, Germany; ${ }^{2}$ Centro Nacional de Ciencia \\ y Tecnología de Alimentos (CITA), Universidad de Costa Rica (UCR), Ciudad Universitaria Rodrigo Facio, código postal \\ 11501-2060, San José, Costa Rica; entomoque@gmail.com
}

Received: 5 August 2021 / Accepted: 25 October 2021

(c) 2021 Wageningen Academic Publishers

OPEN ACCESS @C (1) RESEARCH ARTICLE

\begin{abstract}
Due to its environmental conditions, its efforts towards sustainability and the current cricket rearing activities, the industrial production of edible cricket powder is seen as an economic opportunity for Costa Rica. The feasibility of such a project was explored through a two-stage qualitative research. First, the market needs, product and production requirements were investigated through semi-structured interviews to possible buyers and producers, a visit to an industrial cricket powder production plant and a desk study. During the second stage, the entopreneurial ecosystem in Costa Rica was explored through semi structured interviews to local experts and entopreneurs in order to evaluate the feasibility of complying with the requirements identified in the first stage. Results show that Mexico and the United States are the main potential markets for Costa Rica. The main buyers are food and pet food producers with an average demand of 0.5-2 tons of cricket powder per month. A validated protein content, a gluten-free product and a neutral aroma are key product requirements. For the production, it is required to have an enclosed facility, with temperature and humidity control and a proper food safety and quality management system in place. It is concluded that the current entopreneurial ecosystem in Costa Rica does not allow to meet the international market needs required for commercialising cricket powder. Challenges like the current low production capability, high price, the lack of technical experts and specific regulation on insect production must still be overcome. Though, the main opportunities that would allow such a production are the existent local knowledge on rearing insects, well-established academic, research, and export promotion institutions, governmental small and medium enterprises support programs and the local expertise on exporting butterflies. The creation of an association that defines a national strategy is seen as a necessary step to boost the sector.
\end{abstract}

Keywords: cricket farming, cricket powder processing, crickets as food, entopreneurship, entopreneurial ecosystem

\section{Introduction}

In recent years, investment and funding for entopreneurs has risen specially in Europe and the United States. Current food trends in alternative proteins and efforts made by research organisations and nongovernmental organisations such as the Food and Agriculture Organization of the United Nations (FAO) have been bringing the potential of edible insect food to the public attention (Dossey et al., 2016). Entopreneurs are companies, organisations and individuals working on any edible-insect related businesses such as insect farming, edible-insect food products or advocating the benefits of eating insects (Engstrom, 2019). It has been reported that the number of insect-based start-ups significantly increased between 2010 and 2015 (Dossey et al., 2016). In Latin America, Bermúdez-Serrano (2020) analysed the current entrepreneurial activities and reported a total of 28 companies producing insects as food in the region, from which three companies are classified as 'professional insect farmers', the rest are rather small and infant entrepreneurial ventures. The countries with most identified start-ups in the region are: Mexico, who is leading the list with 13 entopreneurships, Costa Rica with 4 and Brazil with 3 companies (Bermúdez-Serrano, 2020).

Costa Rica is well known internationally since it possesses one of the highest densities of biodiversity of any country in the world (nearly $5 \%$ of the world's biodiversity) (CINDE, 
2020). Due to its location in the tropics, the weather conditions make it possible for insects to grow naturally. A few entrepreneurs have started rearing and selling edible insects and processed products, such as Grillos en Costa Rica, Costa Rica Come Insectos, CRIC and Gricket House (Bermúdez-Serrano, 2020). Costa Rica is one of the countries in Latin America where the tradition of entomophagy was lost, and thus consuming insects is a novelty. In the last years there have been some local private and public initiatives aiming to promote and develop the edible insect sector. The Museum of Insects of the University of Costa Rica (UCR) is one of the main actors in the field, since it has been promoting the consumption of edible insects during the past 10 years (O'Neal, 2019). The National Research Centre for Food Science and Technology (CITA), from the UCR obtained public funding for a project that seeks to develop information around insect-based food products in the country (CITA, 2019). Also, the joint program DESCUBRE of the Promoter of Foreign Commerce (PROCOMER) and the Ministry of Foreign Trade (COMEX) of Costa Rica identified the edible insects value chain among the top ten priorities with export potential (FUNDES, 2019).

Crickets occupy the largest segment (31.6\%) in the world market for edible insects, and it is estimated that they will continue to dominate it (Meticulous Research cited in De Sousa et al., 2018). The most common cricket species that is grown with the purpose to produce food is Acheta domesticus, also known as 'house cricket' (Cortes-Ortiz et al., 2016). Costa Rica is not the exception and $A$. domesticus is the most common edible insect reared by the local entopreneurs (FUNDES, 2019).

Since edible insects are considered a radical innovation, market constraints could have a bigger impact on the success of a start-up (Pascucci et al., 2015). Thus, investigating the viability of a project for producing edible insects is of special importance in a context where uncertainty is high. To make the decision to start a business related to the production of cricket powder in a country like Costa Rica, where entomophagy is not traditional, it is crucial to first understand the market needs and if the required resources are available in the country to sustainably produce and supply the international market with quality products. Therefore, the present study explored the feasibility of producing and exporting cricket powder in Costa Rica, in order to supply the growing international market. The obtained results will help entopreneurs, investors and public authorities make better decisions related to the establishment of a novel insect-based industry in Costa Rica or any other country in the world.

\section{Research methodology}

\section{Research model}

The research approach was exploratory due to the scarcity of previous works on the topic. The research was divided in two stages. The first stage had the objective of investigating the market needs and production requirements related to cricket powder in the international supply chain. The second stage was focused on investigating the current entopreneurial ecosystem in Costa Rica and exploring the feasibility of producing and exporting cricket powder considering the results of stage 1 . The second stage was divided in two sections: first, the existent entopreneurial activities were evaluated in terms of the production compliance to the market needs and production requirements and second, the main opportunities and challenges of the local entopreneurial ecosystem were investigated.

\section{Location and data collection methods}

The field research was conducted from September 2019 to February 2020 in various locations: Germany, Vietnam, Thailand and Costa Rica.

Several qualitative methods were used to extract the data in the different stages of the research: a total of 14 in-depth key informant interviews were carried out and a visit to a cricket powder production facility was performed on October $24^{\text {th }}, 2019$. Additionally, a desk review was conducted. In all interviews, a semi-structured questionnaire was used.

\section{Concepts investigated}

Table 1 shows the main concepts investigated in each stage of the research and the main indicators, which were included in the interview questionnaires.

\section{Description of population and sample}

The selected sampling was non-probability and purposeful, meaning that the researcher selected participants from which the most can be learned, according to their characteristics, experiences, attitudes or perceptions (Cooper and Schindler, 2014; Merriam and Tisdell, 2016). Different samples were used for each stage of the research according to the objective. Some interviewees asked to remain anonymous.

Possible buyer: A quota sampling was performed, with the aim to interview three edible cricket processors to get the insights about the requirements they demand for the cricket powder. However, only one of the contacted companies was willing to participate in the research. The co-founder of a start-up that produces insect-based snacks 
Table 1. Main concepts and indicators investigated in the research.

\begin{tabular}{|c|c|c|c|}
\hline Research stage & Issue investigated & Key concepts & Key indicators \\
\hline \multirow[t]{4}{*}{ Stage 1} & \multirow[t]{3}{*}{$\begin{array}{l}\text { Market needs for } \\
\text { cricket powder }\end{array}$} & Main potential export markets & $\begin{array}{l}\text { Countries that are currently importing cricket powder and could be } \\
\text { potential export markets for Costa Rica }\end{array}$ \\
\hline & & Potential demand & $\begin{array}{l}\text { - Type of companies willing to buy cricket powder } \\
\text { - Location of possible buyers and suppliers } \\
\text { - Average demand per client } \\
\text { - Products demanded and price }\end{array}$ \\
\hline & & Main product requirements & Main quality and food safety requirements required by buyers \\
\hline & $\begin{array}{l}\text { Production } \\
\text { requirements }\end{array}$ & $\begin{array}{l}\text { Cricket rearing } \\
\text { Post-processing for obtaining } \\
\text { the cricket powder }\end{array}$ & $\begin{array}{l}\text { - Technology/equipment used } \\
\text { - Characteristics of the facilities } \\
\text { - Environmental conditions } \\
\text { - Raw materials and supplies } \\
\text { - Personnel skills } \\
\text { - Required quality/food safety management systems }\end{array}$ \\
\hline \multirow[t]{8}{*}{ Stage 2} & \multirow[t]{3}{*}{$\begin{array}{l}\text { Existent entopreneurial } \\
\text { activities in Costa Rica }\end{array}$} & Current production conditions & $\begin{array}{l}\text { - Compliance of facility requirements } \\
\text { - Equipment/technology used }\end{array}$ \\
\hline & & Output capacity & - Total production capacity per month \\
\hline & & Price & - Price per kg of cricket powder \\
\hline & \multirow{5}{*}{$\begin{array}{l}\text { Main opportunities } \\
\text { and challenges of the } \\
\text { local entopreneurial } \\
\text { ecosystem in Costa } \\
\text { Rica }\end{array}$} & $\begin{array}{l}\text { Local and international market } \\
\text { potential } \\
\text { Social and cultural orientation }\end{array}$ & $\begin{array}{l}\text { - International image of the country related to the production of insects. } \\
\text { - Local off-take market for products containing cricket powder. } \\
\text { - Public opinion towards edible insects } \\
\text { - Consumer openness to try products with insects. }\end{array}$ \\
\hline & & $\begin{array}{l}\text { Finance and support for } \\
\text { entrepreneurs }\end{array}$ & $\begin{array}{l}\text { - Public policies related to entrepreneurship promotion investment } \\
\text { support and fiscal policy to support edible insect production } \\
\text { - Private financing opportunities (Venture Capital and others) for edible } \\
\text { insect production, }\end{array}$ \\
\hline & & Access to knowledge & $\begin{array}{l}\text { - Available knowledge related to edible insect farming } \\
\text { - Knowledge transfer related to edible insect farming }\end{array}$ \\
\hline & & Regulation & $\begin{array}{l}\text { Local and international regulations related to the production and } \\
\text { commercialisation of edible insects }\end{array}$ \\
\hline & & $\begin{array}{l}\text { Stakeholder networks and } \\
\text { strategic orientation }\end{array}$ & $\begin{array}{l}\text { - Innovation networks } \\
\text { - Public-private articulation }\end{array}$ \\
\hline
\end{tabular}

in Berlin, Germany was interviewed. The interviewer asked to remain anonymous.

Producers: One of the objectives of the research was to analyse the production requirements for cricket powder as food in a tropical country like Costa Rica. The sampling was conducted accordingly, looking for industrial cricket powder producers located in a tropical country. Four companies were contacted, out of which, two agreed to participate. Two industrial producers of cricket powder were interviewed. Producer 1 is a company located in Vietnam that asked to remain anonymous and Producer 2 is Global Bugs Asia, a cricket powder production facility located in Hua Hin, Thailand, and funded by two Swedish entrepreneurs. A facility visit was conducted at the Global Bugs production site in Hua Hin, Thailand.
Local experts: Two local technical experts (LTE) on entomology were interviewed: the biologist technician of The Museum of Insects of the University of Costa Rica (LTE 1) and the Head Entomologist of the Experimental Butterfly Garden of the University of Costa Rica (LTE 2), both initiators of the edible insect rearing in the country. In addition, and in order to understand the business ecosystem and the support entrepreneurs can get in Costa Rica, a local business expert (LBE) was interviewed. The expert works as program coordinator at the Agency for Entrepreneurship Management of the University of Costa Rica (AUGE).

Local entopreneurs: Four entopreneurships were identified in Costa Rica producing either crickets or cricket-based products: Gricket House (Local Entopreneur 1) and CRIC (local entopreneur 2), Grillos en Costa Rica (local entopreneur 3) and CR Come Insectos (local entopreneur 4). 
The founders of these business were interviewed to get insights of their main challenges and opportunities.

International experts: Three international experts in the edible insect sector were interviewed: Anne Deguerry, President of Asian Food and Feed Insect Association (AFFIA), Joash Matthew, Scientific Affairs Representative of the International Platform of Insects as Food and Feed (IPIFF) and Josh Galt, an independent consultant on edible insects. In addition, an investor interested in the edible insect sector in Costa Rica was interviewed in order to understand the key elements that would make him want to invest in the project.

\section{Data management}

All conducted interviews were audio-recorded (with the permission of the interviewees) to facilitate the processing of the data. In the case of the facility visit, only pictures of the outside of the facility were allowed and notes were taken during the visit. When possible also pictures of the production areas were taken after permission was granted from the interviewees. The responses of the interviews were transcribed in their original language (either Spanish or English), and successively translated to English when applicable. Afterwards, the transcriptions were revised in order to assure coherence with the original data source, and later entered into the software tool MAXQDA (Version 20.0.8; 2020; VERBI GmbH, Berlin, Germany) for the posterior analysis. The data was analysed following the qualitative content analysis approach mentioned in Bryman (2004: 542), for the analysis of text, by considering the context and creating categories out of the data.

\section{Results}

\section{Understanding market needs}

The results presented in Table 2 show that there is a potential market for the Costa Rican entopreneurs to export to Mexico, North America (Canada and the USA) and Europe. Of these, the most approachable markets are considered to be Mexico and North America due to the regulation constraints in Europe.

According to the interviewees, the average demand per month and client is $0.5-2$ tons, with an average price of 50-60 USD $/ \mathrm{kg}$ in Europe. This price is perceived as too high and experts interviewed considered it should come down to $45 \mathrm{USD} / \mathrm{kg}$ and eventually $20 \mathrm{USD} / \mathrm{kg}$ to make cricket powder more competitive. The price mentioned by the interviewees agrees with the values reported by Reverberi (2021), which are between 60 and 90 USD/kg for the cricket flour in Europe. In 2020 cricket flour prices in Europe were more expensive than the ones from the North America ( $40 \mathrm{USD} / \mathrm{kg}$ ) and Thailand (20 USD $/ \mathrm{kg}$ ) markets, and is also reported that some of the biggest factory farms in North America and Europe are trying to reduce cricket flour costs by including automation in their production practices (Reverberi, 2021).

According to the two producers interviewed, their main buyers of cricket powder are food producers and pet food producers. Interestingly, both producers mentioned Japan as a buyer of cricket powder for the cosmetic and pharmaceutical industry, which presents a great potential in terms of innovation. In this context, the IPIFF (2019b)

Table 2. Main results obtained for the market needs of cricket powder for Costa Rican entopreneurs.

\begin{tabular}{|c|c|c|}
\hline Key issue investigated & Main results & Considerations \\
\hline Main export markets & Mexico, North America and Europe & $\begin{array}{l}\text { Japan is a growing market, but considering its location it may be } \\
\text { difficult to compete. } \\
\text { Expert recommendation is to first target the US market rather than } \\
\text { the European one due to the closeness and the complicated } \\
\text { regulation in Europe related to edible insects }\end{array}$ \\
\hline Average demand & $0.5-2$ tons per month/client & - \\
\hline Price & $50-60$ USD $/ \mathrm{kg}$ & $\begin{array}{l}\text { This price is perceived as too high to be competitive in the market. } \\
\text { The goal would be to reach less than } 45 \text { USD per kg (and ideally } \\
20 \text { USD } / \mathrm{kg} \text { ). }\end{array}$ \\
\hline Type of buyers & $\begin{array}{l}\text { Food producers, pet food producers, } \\
\text { cosmetic and pharmaceutical industry. }\end{array}$ & Considering the scope of the research, the feed industry is excluded \\
\hline Type of products & $\begin{array}{l}\text { Natural cricket powder, defatted cricket } \\
\text { powder, cricket oil }\end{array}$ & To obtain each type, additional processing steps are required. \\
\hline
\end{tabular}


reports that pet food is a mainstream market for European insect producers, since insect products are well-suited to the needs of pet food, due to their high digestibility and palatability. In addition, the results show that although natural cricket powder is the main product commercialised, defatted cricket powder and cricket oil are products that can even have a higher market value.

In relation to the main findings observed for the product requirements in terms of quality and food safety, the protein content was referred to as the most important quality aspect considered by the buyers, who are expecting a minimum of 60 to $70 \%$ protein in the powder. The protein content must be validated by a laboratory analysis (Figure 1). This cost must be considered by producers. In addition, avoiding a fishy odour was mentioned as a key quality indicator. One interesting result was the requirement of gluten free cricket powder by some buyers due to current consumer trends. In this sense, it must be considered by producers that the feed of the crickets must be gluten free (less than $20 \mathrm{mg} / \mathrm{kg}$ ) to comply with this requirement. To be able to assure this to the buyers, an adequate traceability system must be in place, meaning that all materials used during the production can be traced down from the final product (IPIFF, 2019a). In addition, microbiological and chemical analysis are usually necessary to comply with the national regulations in the country of origin, as well as the regulations of the export market. Producers have to have a deep knowledge of these regulations to assure compliance.

\section{Production requirements}

Once it was clear what the buyers usually expect from the cricket powder, it was important to understand the production steps necessary to comply with the required

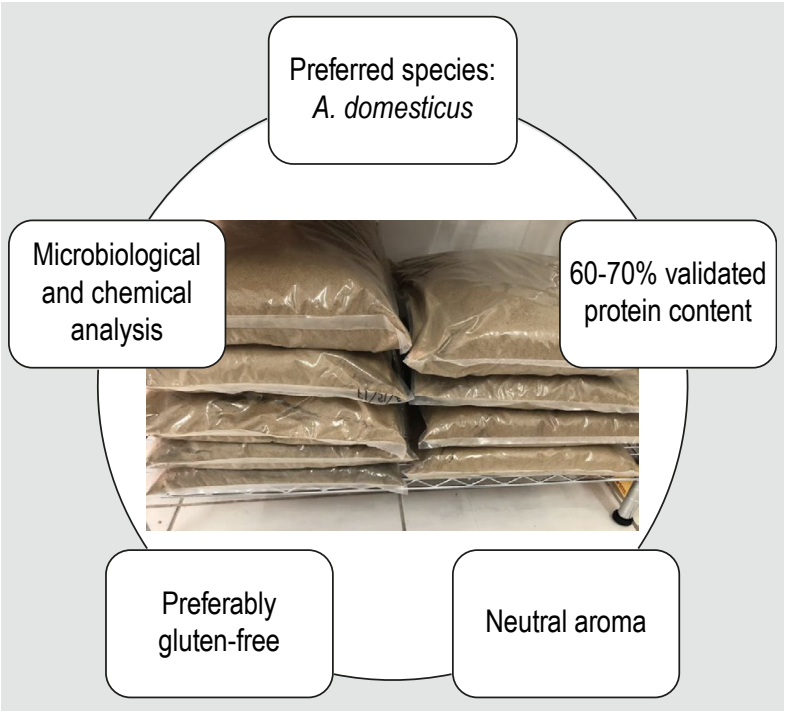

Figure 1. Usual product requirements for cricket powder as food. specifications. Due to the novelty of the sector, production systems are not standardised and can be significantly different among producers. For example, interviewed producers have different ways of ensuring a stable sourcing of fresh crickets. Producer 1 relies on a network of farmers supplying them with raw material under their strict supervision. Crickets are then processed into cricket powder and other subproducts in their manufacturing facility. On the other hand, producer 2 has a centralised facility, in which they farm and further process the crickets into cricket powder. Since it was not possible to visit the facility of producer 1, results included in Figure 2 and Table 3 refer solely to the observations made at the facility visit of producer 2 . Figure 2 schematises the main processing steps producer 2 uses to obtain cricket powder, while Table 3 summarises the main production requirements observed at their production facility. Results obtained from producer's 1 interview are used to complement these observations.

Regarding the infrastructure for an industrial production, the main basic requirement observed during the facility visit is that it was enclosed. The rearing and further processing steps were located in a structure that has a roof and walls and where the entrance of other species is avoided. The walls were smooth and easy to clean, as well as the floors and ceilings. These conditions comply with the requirements listed in the IPIFF Guide on Good Hygiene Practices (IPIFF, 2019a). The main areas observed in the visited facility are: a warehouse to store materials, the farm where crickets are reared (with a separate area for the eggs), a washing area for containers and the post-processing area as well as a quality laboratory.

In terms of the supplies and equipment needed, the main costs are related to the metallic racks, plastic containers,

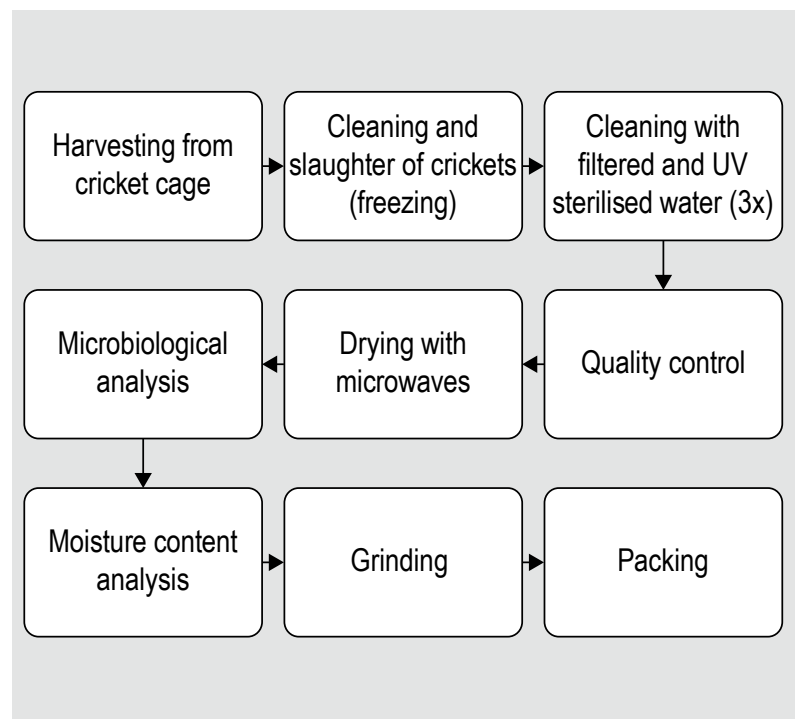

Figure 2. Main processing steps for the production of cricket powder as observed in the visited facility (producer 2). 
Table 3. Main production requirements collected from the visited facility (producer 2).

\begin{tabular}{|c|c|}
\hline Key indicator & Results \\
\hline Plant layout & $\begin{array}{l}\text { The main areas are: warehouse, farm (with a separated room for egg development), containers washing } \\
\text { area, post-processing area, quality laboratory. }\end{array}$ \\
\hline Infrastructure & $\begin{array}{l}\text { Outside: enclosed facility. It is important to have a sealed area, to avoid entomophagos. } \\
\text { Inside: Metallic racks, smooth walls, floors and ceilings. All surfaces are easily cleanable. }\end{array}$ \\
\hline Environmental conditions in the farm & $\begin{array}{l}\text { Temperature: } 30-32{ }^{\circ} \mathrm{C} \\
\text { Humidity: } 50-60 \% \\
\text { (Temperature and humidity conditions in the separated room for egg development are higher). }\end{array}$ \\
\hline Quality and Food Safety Assurance & $\begin{array}{l}\text { - Compliance to FDA regulation } \\
\text { - Hygiene attire available for personnel and visitors } \\
\text { - Register the production } \\
\text { - Appropriate labelling }\end{array}$ \\
\hline Personnel & $\begin{array}{l}\text { - Due diligence and project managements skills are needed, as well as openness to trial and error. } \\
\text { - At least } 2 \text { operators in the farm } \\
\text { - } 1 \text { operator for the laboratory area }\end{array}$ \\
\hline Required technology & Microwave dryer (imported from China), grinder \\
\hline Supplies & $\begin{array}{l}\text { Plastic containers (Figure } 3 \text { ) and egg cartons are the main supplies } \\
\text { The containers are washed before and after use. Egg cartons are placed in these containers to increase } \\
\text { the area for the crickets. The cartons are sealed with a substance which controls pests and increases } \\
\text { productivity (the specific name was not shared). }\end{array}$ \\
\hline Feed requirements & $\begin{array}{l}\text { The development is performed along with feed companies and academia. It is critical to optimise the process. } \\
\text { It requires approx. } 1 \text { year of research. }\end{array}$ \\
\hline Water requirements & $\begin{array}{l}\text { It must always be available at all times. The water supply method is critical since water drops can be deadly } \\
\text { to instars. }\end{array}$ \\
\hline
\end{tabular}

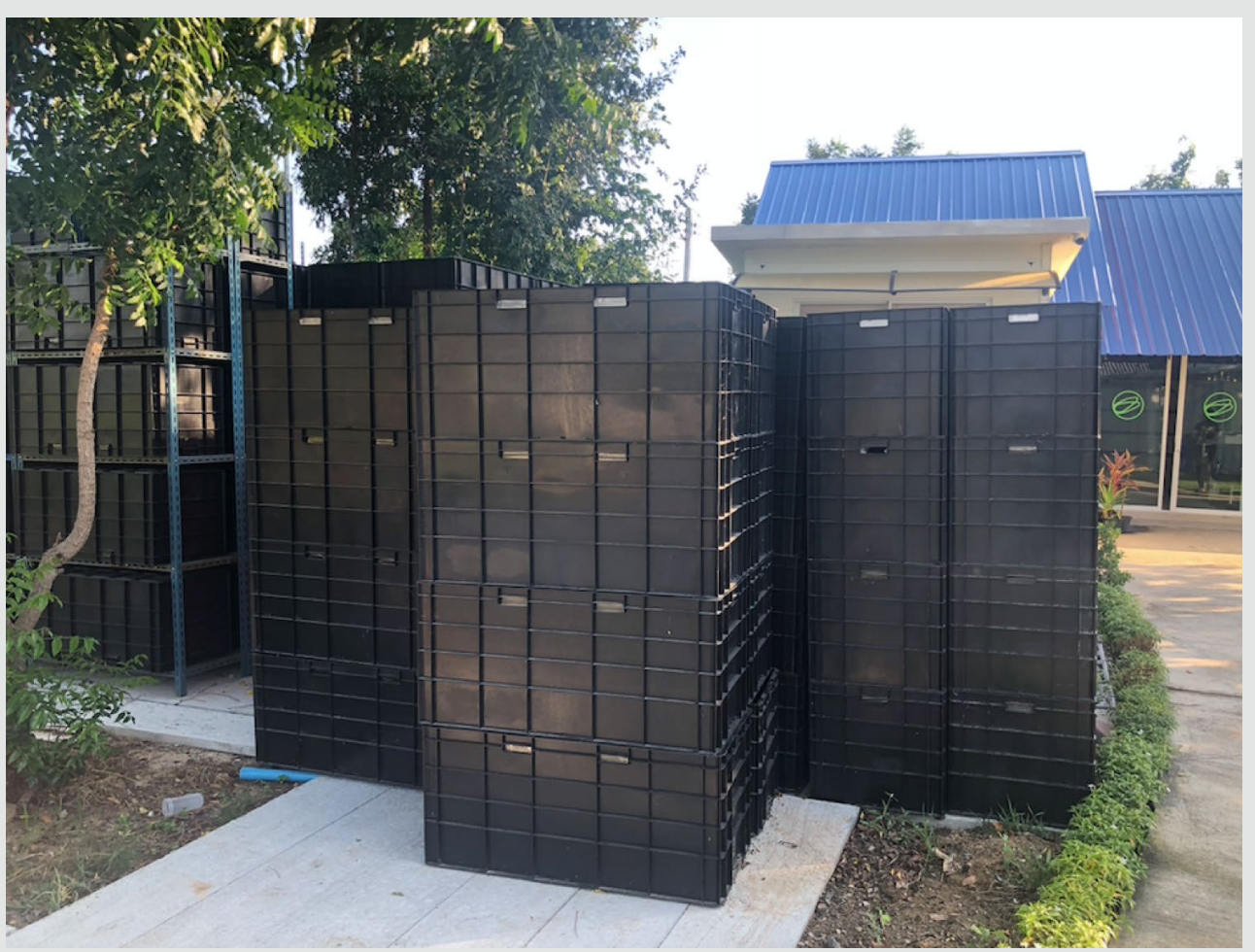

Figure 3. Plastic containers used by producer 2 to rear crickets. 
egg cartons, feed and the post processing steps supplies. In this case, the microwave dryer and the grinder to obtain the cricket powder were the two main technological equipment identified during the visit. The microwave dryer is specific for crickets and was bought in China. It is important to mention that this is only one of various types of dryers available in the market and does not necessarily mean that it is the best option. Considering the novelty of the sector, each producer decides on the best equipment and processing steps to optimise their process. Thus, an analysis of the available equipment in the market should be also part of the planning phase before starting a project to produce cricket powder.

In terms of the farming, both producers stated that although water is one of the key critical factors for the survival of the crickets it must also be considered that it may be deadly for the instars, due to their small size. Thus, special attention must be placed on the water disposing system. In the case of the feed, both producers agreed that this is also one of the key success factors of cricket production, since the feed must be as standardised as possible. Even if chicken concentrate can be used as a feed option for crickets, both producers stated that an intense research and development phase is needed to formulate the right feed. In their cases, this process took approximately 1 year, with the help of academic institutions and commercial feed companies.

Both interviewed producers agreed that environmental conditions are critical for the optimisation of the crickets' life cycle. In the visited facility, temperature was controlled at $30-32{ }^{\circ} \mathrm{C}$, while humidity was kept between $50-60 \%$. These values are in line with Cortes-Ortiz et al. (2016) who report that cricket farmers use temperature ranges between 29.5 and $33{ }^{\circ} \mathrm{C}$ in their rearing areas and Mott (2017) that suggest a relative humidity of $50-60 \%$.

In addition, both producers have a quality and food safety system in place. Compliance with GMPs and HACCP are expected but a certification is not a limiting requirement according to the interviewees. However, knowing the sector will move towards it, both of the interviewed producers were already certified under a food safety scheme. Producer 2 obtained a HACCP certification from Intertek for the post-processing steps.

\section{Existing entopreneurial activities in Costa Rica}

Four entopreneurs were identified in Costa Rica producing insects for human consumption and two more producing animal feed. The novel edible insect sector in Costa Rica shows two well-defined distinct producers of crickets: the traditional ones and the ones with an industrial approach. Local entopreneurs 1, 3 and 4 are rearing at home, in special areas designed for it, while entopreneurs 2 have a separate area located in Siquirres (Limón, Costa Rica). The researcher was only able to observe the insect farm of local entopreneur 4 (Figure 4). Both local entopreneurs 1 and 2 are aware of the facility requirements in terms of quality and food safety and have them in their future plans while local entopreneurs 3 and 4 (traditional farmers) are not fully aware of the international requirements and its implications.

All the entopreneurs are rearing $A$. domesticus (except for entopreneur 3, who rears field crickets). In general, there are improvement opportunities in terms of the crickets' life cycle, since the entopreneurs mentioned an average cycle of 8-14 weeks.

Although there is knowledge about the nutritional requirements of the crickets, entopreneurs have established their formula on their own without the support of the academia or commercial providers that are present in the country. Traditional farmers are buying fruits and vegetables from the local markets. This is a great opportunity that can be explored in order to come up with a standardised cricket feed since there is enough technical knowledge and research institutions that could support the development of an adequate feed. For example, LTE 2 suggested a combination of organic food waste from local food manufacturers and chicken concentrate, in order to get the adequate protein amount needed by the crickets.

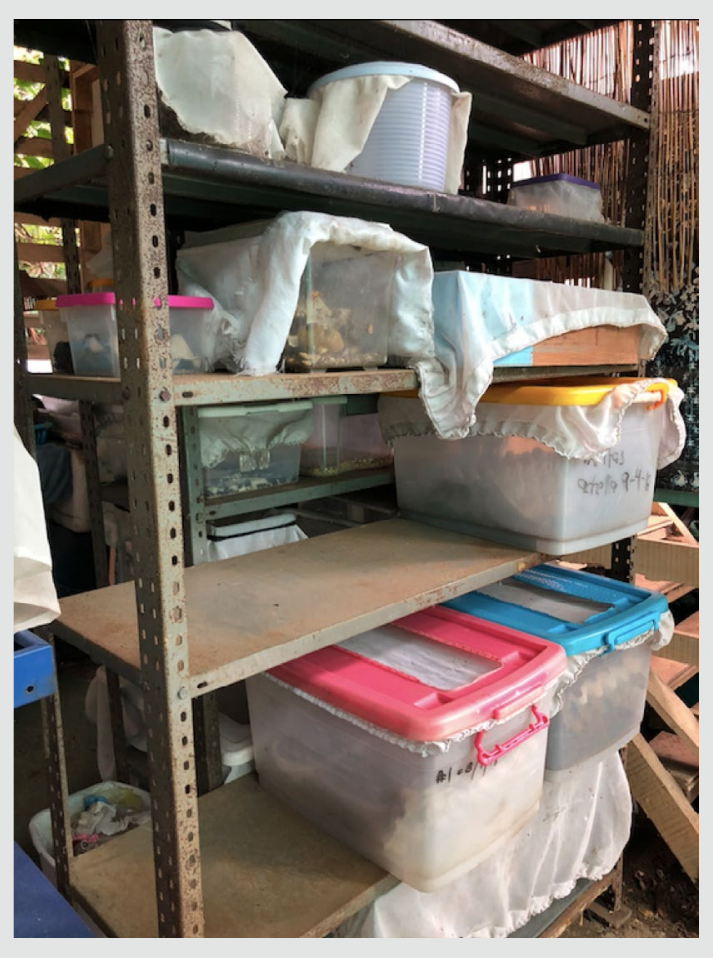

Figure 4. Cricket rearing containers used by local entopreneur 4. 
Clearly, the local output capacity is not big enough to comply with the current international demand. The estimated output capacity in Costa Rica is between $1-5 \mathrm{~kg}$ (small-scale production) to a maximum of $500 \mathrm{~kg}$ (large-scale production) cricket powder per month but not on a continuous basis, which means that the country could not even supply a single client with the current production capacity, considering the demand is at least 0.5-2 tons per month. Thus, upscaling is the main challenge to be addressed in order to comply with the market needs. This result was expected, since the cricket production sector in Costa Rica is relatively new, as in the rest of the world. In fact, the IPIFF also considered the need to upscale as the main challenge for the European insect sector (IPIFF, 2019b).

In addition, the current price of cricket powder is one of the biggest constraints identified. Two different situations were detected: the price of cricket powder produced by traditional farmers would be 500-1000 USD per kg (10 times higher than the current international price) since their average price per dried cricket is 0.2-0.4 USD. On the other hand, the more industrial start-ups claim to have prices between 40-70 USD per $\mathrm{kg}$ for cricket powder which is in line with the international price mentioned by the possible buyer. However, according to the experts interviewed this price should still be lowered down if they would like to be more competitive in the future. In both cases, prices are above the desired threshold. This is a general problem of the edible insect sector; the production costs tend to be high when compared to traditional protein sources (Van Huis, 2020).

Out of the four companies interviewed, only local entopreneur 2 has actual plans to commercialise cricket powder. Traditional rearers sell mostly whole crickets. Thus, Costa Rica is far behind the expectations of the market in terms of functionality and should thus, develop more innovative products that allow local small and medium enterprises (SMEs) to immerse in the international value chain. Additionally, none of the local entopreneurs are providing gluten free products and only one conducts validated laboratory analysis. Thus, this is a topic that should be considered as part of a management system in order to be able to comply with client's requirements.

\section{Main opportunities and challenges of the local entopreneurial ecosystem}

Table 4 summarises the main opportunities and challenges identified for the local entrepreneurial system considering the main concepts investigated.

Table 4. Main opportunities and challenges identified in the Costa Rican entopreneurial ecosystem.

\begin{tabular}{|c|c|c|}
\hline Concept investigated & Main opportunities & Main challenges \\
\hline $\begin{array}{l}\text { Local and international } \\
\text { market potential }\end{array}$ & $\begin{array}{l}\text { - Costa Rica already has a long history of exporting insects } \\
\text { (butterflies). } \\
\text { - Costa Rica has an international image as a sustainable } \\
\text { country. } \\
\text { - There are existent export opportunities for edible insects. }\end{array}$ & $\begin{array}{l}\text { - Lack of a natural offtake market } \\
\text { - Current production capacity is too low } \\
\text { - Current cricket powder prices are not competitive }\end{array}$ \\
\hline $\begin{array}{l}\text { Social and cultural } \\
\text { orientation }\end{array}$ & $\begin{array}{l}\text { - The local public seems to be interested and curious about } \\
\text { eating insects. }\end{array}$ & $\begin{array}{l}\text { - Lack of consumer knowledge on consumption of insects } \\
\text { and their benefits. } \\
\text { - General poor innovation culture }\end{array}$ \\
\hline Regulation & - Existent solid regulation related to wildlife protection. & $\begin{array}{l}\text { - No specific legislation for edible insects exists. } \\
\text { - Lack of clarity in the existing regulation. } \\
\text { - The current legislation is aimed at a higher scale } \\
\text { production and does not include small entopreneurs. }\end{array}$ \\
\hline $\begin{array}{l}\text { Finance and support for } \\
\text { entrepreneurs }\end{array}$ & $\begin{array}{l}\text { - Existent small and medium enterprises support policy } \\
\text { of the government } \\
\text { - There are existent support institutions on } \\
\text { entrepreneurship, innovation and business promotion }\end{array}$ & - Low private financing opportunities for entrepreneurs. \\
\hline Access to knowledge & $\begin{array}{l}\text { - Academia is playing a key role in knowledge transfer. } \\
\text { - There is knowledge on rearing crickets among producers } \\
\text { and technical experts. } \\
\text { - Existent research institutions and laboratories }\end{array}$ & $\begin{array}{l}\text { - Lack of experts on mass production of edible insects. } \\
\text { - Low availability of technical experts on rearing insects. } \\
\text { - Low training offer. } \\
\text { - Low research on edible insects }\end{array}$ \\
\hline $\begin{array}{l}\text { Stakeholder networks } \\
\text { and strategic orientation }\end{array}$ & $\begin{array}{l}\text { - Producers know each other and have knowledge transfer } \\
\text { practices. } \\
\text { - The DESCUBRE Project promotes innovative agro- } \\
\text { industrial projects. }\end{array}$ & $\begin{array}{l}\text { - There is no articulation between the public and private } \\
\text { sectors and the academia } \\
\text { - Lack of a sense of cooperation culture between producers }\end{array}$ \\
\hline
\end{tabular}




\section{Local and international market potential}

One of the main opportunities mentioned by the interviewees is that local producers have already been contacted by international buyers willing to buy insect products from them, which confirms the existent international market potential. However, in most cases producers had to turn down the offers because they could not comply with the demanded product quantities, which makes it even more urgent to increase the output capacity.

In addition, one of the most interesting results is that Costa Rica already has more than 40 years of history of producing and exporting butterflies, being the main world exporter of butterfly pupae to international markets such as the United States and Europe (Umaña, 2020). This position in the international market combined with the well-known image of being a sustainable country, aligns perfectly with the purpose of an edible insect production and represents a very interesting marketing potential for the country and local entopreneurs. Moreover, the fact that there is already an insect-based industry (even if butterflies are reared differently and sold to a completely different market) it has led to developing an ecosystem that would be able to use the acquired know-how and resources in terms of producers' networks, regulations and training efforts as inputs to the development of an insect-based food production.

Although there is already a local demand for the existing insect-based products, the international expert pointed out that this may be not enough to consider it as an established offtake market. This could make the country less attractive to investors due to the fact that the produced cricket products cannot necessarily be commercialised internally, which is the case in Thailand or Mexico, where the internal demand is higher than the offer (RamosElorduy et al., 2006).

\section{Social and cultural orientation}

The general openness of the local consumers to try insects, as reported by the local entopreneurs represents an opportunity to easily introduce a cricket production hub in the country that would be well accepted. However, there is still lack of consumer knowledge on edible insects and their benefits, which can have an impact on the other concepts investigated, such as the regulation, for example making it necessary to explain to public regulators, why the production of edible insects is important.

Moreover, issues like the poor innovation culture could affect the development of an edible insect sector in Costa Rica. In this line, Monge-Gonzalez (2016: 46) states that it can perhaps be claimed that Costa Rica lacks a culture of innovation'. This aspect represents a constraint for entopreneurs which could have problems developing the necessary innovative products and technologies.

\section{Finance and support for entrepreneurs}

The existent SME support strategy led by the government is seen as an opportunity. The government of Costa Rica has already identified the importance of SMEs in the local economy, and thus, has a strategy led by the Ministry of Commerce to strengthen them. In Costa Rica, only SMEs are potential beneficiaries of state support for investment in innovation activities. This is definitely an opportunity for cricket powder producers, since the funds can be used for technology development, innovation and patent creation, technology transfer, human capital development and technological services development (Monge-Gonzalez, 2016).

Nevertheless, the country still does not have programs in place to support fast growing start-ups. It seems there is still not enough knowledge in the country on how innovation in such start-ups works, which is a downside for entrepreneurs like entopreneur 2 .

Costa Rica already has working institutions supporting entrepreneurs and innovation, such as AUGE, PROINNOVA, and incubators such as IMPACTHUB and CARICACO. This is without doubt a great benefit for the entrepreneurs, who can get advice to grow their businesses. Furthermore, the role of PROCOMER in promoting exports was acknowledged by the local entopreneurs. This public institution provides support to producers willing to export, not only through advice and training but also through international marketing strategies such as the participation in international fair trades (PROCOMER, 2019).

However, there are still challenges that need to be overcome, such as the low private financial support for entopreneurs, who normally have to self-finance and thus cannot grow as fast as required. This result was expected, since according to the Enterprise Survey for Costa Rica (World Bank, 2013), many companies claim that their main obstacle related to the business environment is lack of access to funding. In addition, Monge-Gonzalez (2016) considers that the shortage of venture capital is obvious in Costa Rica, where only businesses in the information and communication technologies sector have access to such resources.

\section{Regulation}

The legislation is clearly the main constraint for a possible development of a cricket powder production hub in Costa Rica. The existent legislation for wildlife protection which considers insect farms was not specifically created to include edible insects, but these are included by default, 
causing that some requirements are not really applicable and causing confusion and misinterpretations of the law.

It is difficult for producers to get in line with the regulation. First, because the regulation does not take into consideration small producers and the costs associated are too high for the existing one. Second, because government officials show lack of knowledge on the applicable requirements to insect production, not being able to appropriately process the paperwork. The bureaucracy was also mentioned as one of the main constraints for entopreneurs.

From a governmental perspective, there is also the challenge of the number of technical experts available. Since there are not enough for the existing butterflies' farms, and thus, would also not be enough in case more cricket farms should be inspected.

The existence of a law protecting wildlife can be seen as an opportunity and as a constraint at the same time. One the one hand, the fact that the country protects its wildlife must be seen with good eyes, since the lack of a solid regulation to control inappropriate exploitation of wildlife is a risk stated by Ramos-Elorduy et al. (2006) that has caused the extinction of several insect species in Mexico. However, the same law is blocking the efforts of small entopreneurs to legalise their farms and increasing their production, limiting the growth of the sector and the possible economic benefits related to it. Thus, it is important to identify a balance between the possible risks and the benefits of this legislation to insect rearers.

\section{Access to knowledge}

It was evident that Costa Rica has an infant and incipient edible insect sector. But, some knowledge resources are present, such as existent entopreneurs with years of experience rearing insects. Moreover, it was evident that academia is already playing a key role in developing an edible insect sector, especially the University of Costa Rica (UCR) through the Museum of Insects, the School of Nutrition and the National Center for Science and Food Technology (CITA). As the study's results show, the role of the Museum of Insects during the last 10 years has had a direct impact on the existent entopreneurial activities, as well as the training course provided by the School of Nutrition. Thanks mainly to knowledge transfer from the University of Costa Rica and the private individual efforts of the existent entopreneurs, there is basic knowledge on the rearing of insects, which is an important starting point for scaling up a cricket powder production.

Although Costa Rica is a middle-income country, there are several institutions that have experience in research, specifically on food and animal nutrition, such as CITA and the Center for Animal Nutrition (CINA) (both located in the
UCR), which would play a key role on supporting the private sector with research and development projects. Also, Costa Rica has a well-established infrastructure of laboratories on food analyses and microbiology, solely the UCR has a network of 64 laboratories in the fields of molecular and cell biology, chemistry, food and materials technologies, and structural models (Crespi, 2010), making it possible to comply with the quality control standards required by buyers. Similarly, although local entopreneurs are far from obtaining a certification, the advantage is that there are certification companies in Costa Rica with experience in certifying food processing companies, who can train, advise and perform the required service.

However, there are still challenges to be overcome such as the limited number of technical experts in the production of insects, especially when it comes to large scale. As a result, the training offered on large producing insects is limited. Also, although the Museum of Insects has done a great job in promoting entomophagy and insect rearing there is not really a strategy to develop the sector and no funding is specifically assigned to this area, having also limited personnel.

\section{Stakeholder networks and strategic orientation}

The lack of a common strategy between the private and public sector was noted as a challenge, since these actors usually seem to have different goals and rather fight against each other instead of cooperating. It has been reported that there is a weak interaction framework between universities and research centres and the private sector. For instance, conducting joint research projects occurs sporadically (An et al., 2015).

In this context, the joint program DESCUBRE is a great step in that direction. This is a public-private alliance articulated by the Ministry of Foreign Commerce (COMEX), the Ministry of Agriculture (MAG), the Promoter of Foreign Commerce (PROCOMER) and The Costa Rican Investment Promotion Agency (CINDE) and The Development Banking System with the participation of the private sector and academia. The aim of the program is the diversification of agriculture and fishing and the attraction of investments in rural areas (DESCUBRE, 2020). The fact that edible insects were identified among the ten priorities in this program draws an excellent opportunity to develop the sector.

Other challenges are related to the poor formal network existent between producers, who do not collaborate with each other on a common goal. Unfortunately, this result also goes in line with the international character of the edible insect sector, which is characterised as 'too secretive' as already reported by Van Huis and Tomberlin (2017). One of the main reasons for this behaviour is that entrepreneurs want to protect their know-how and fear being copied by 
others, but also it may be related to the fact that they avoid revealing how small the business is, which would repel potential investors.

\section{Discussion and conclusion}

Costa Rica is a small country with a huge potential in terms of production of cricket powder due to its strategic location in the tropics and near potential markets as Mexico and the United States, as well as its economic and political stability in comparison to other countries in the region. Moreover, Costa Rica has an international status as a sustainable country and a unique history of exporting insects to the world, thanks to a 40 year-long private strategy of butterflies' export to Europe and Asia.

Considering the novelty of the sector, there are clearly still constraints that must be overcome in order for the country to become a main producer and exporter of cricket powder. First, entopreneurs are far from complying with the market needs and production requirements. Although there are already private initiatives to start producing on a larger scale, the current output capacity is not even big enough to supply the requirements of one client and prices are not competitive at all. Therefore, scaling the production is the key challenge that Costa Rica must overcome not only for being able to comply with the existing demand but also to reduce the price for being more competitive in the international market.

In order to scale the production, it is first necessary to analyse what would be the best supply chain model to achieve this. The first option is to promote centralised production plants, while the second is to work into the establishment of small and medium scale cricket farmers that would provide fresh crickets to a post-processor in charge of converting them into more value-added products. Considering the success of the latter model in Thailand, where thousands of small and medium family farmers are able to produce large quantities of crickets at very low prices (Halloran et al., 2017), it is recommended to analyse the viability of this option in Costa Rica. Even though the weather in both countries is similar, other factors like labour costs, geography, and access to feed, as well as the willingness of farmers to start rearing crickets need to be considered.

In order to select the best model, more research is necessary, especially in terms of its financial viability. Understanding the costs associated with farming and processing cricket powder is of importance before starting such a project. The current research can be used as a base for a financial analysis, considering the costs related to production requirements mentioned: personnel, rearing supplies (boxes, egg cartons, plastic containers), selection, purchase, installation and maintenance of processing equipment (freezers, dryer, grinder), water and electricity, feed and its formulation. The cost related to laboratory analysis and implementation of a food safety management system is also to be included, as well as a possible certification. Moreover, normal costs of running a business such as sales and marketing need to be considered.

The second biggest challenge identified in Costa Rica is the lack of legislation: there is no specifically designed legislation for edible insect production, and the existing legislation is unclear, making it difficult for entopreneurs to legalise their productions. In addition, the costs associated with the legislation are not affordable for a small-scale production, leaving small entopreneurs in the informality. It has extensively been reported that the current lack of legislation for edible insect production and commercialisation is one of the main challenges for the widespread use of insects as food (Rumpold and Schlüter, 2013; Van Huis, 2020). In fact, the IPIFF reports that the legal framework was the main factor impacting the growth of the insect sector in 2019 (IPIFF, 2019b).

The third challenge identified is related to resource constraints. Limited financing options, no technical experts specialised in mass producing insects, and almost no existing training offer for interested entrepreneurs should be considered from the resource-based perspective. Thus, there is a great opportunity for researchers and insect experts to design and offer training courses.

Although the edible insect sector is still infant, Costa Rica shows already 10 years of experience promoting their consumption and in recent years also the rearing of insects has to be implemented at low capacity level. Thus, there is a knowledge base in the academic and private sector in small scale production and also, an openness from the public related to the topic of edible insects. There are already explicit export opportunities and some informal networks between producers. In this regard Thailand can serve as an example for cricket powder production in Costa Rica. There, when cricket farming was introduced in the 90s, most farmers were small with one to ten concrete breeding containers, but with the time the business evolved to a small and medium enterprise and cricket farming changed from an additional source of income to becoming the primary income source for most farmers (Hanboonsong et al., 2013).

Collaboration is key for developing such a new sector. The success story of the Netherlands clearly shows that the strong organisation of the Dutch edible insect industry, where the insect producer's association has connections with the national governments and local public representatives as well as with knowledge institutes (Vantomme, 2018) plays a very important role. Therefore, Costa Rica should learn from the lessons of the butterfly sector and better articulate common goals between the 
stakeholders at different levels. The University of Costa Rica and The Museum of Insects should take over a leadership role in order to further develop the existent edible insect sector. Indeed, producing edible insects on a mass scale for food is considered a radical innovation. Thus, the lack of technical knowledge specifically related to the topic is a common concern and it has been recommended to develop technicians and engineers through university-industry collaboration (An et al., 2015).

Additionally, research institutions could be the key actors in developing and promoting a favourable legislation of edible insect production in Costa Rica. Finally, the lack of a formal support network between existent producers on one side and the existing economic promotion agencies on the other side calls for the establishment of an insect producer's association following the Dutch example in order to deal more successfully with the existing resource constraints.

\section{Acknowledgements}

The field research in Costa Rica was financed by DAAD and supported by the University of Costa Rica and the National Research Centre for Food Science and Technology (CITA) as part of the project B9611 'Insect consumption and its application in food matrices in Costa Rica: challenges and opportunities of a potential strategy for strengthening national food security'

\section{References}

Agencia Costarricense de Promoción de Inversiones (CINDE), 2020. Why Costa Rica? CINDE, San José, Costa Rica. Available at: http:// www.cinde.org/en/why

An, G., Oh, D.S. and Monge-González, R., 2015. Supporting mechanisms for SMEs: strengthening innovative capacity and establishing linkages in global value chains. In: 2014/2015 knowledge sharing program with Costa Rica. Strengthening institutions and support mechanism to foster innovation in Costa Rica. Ministry of Strategy and Finance, Seoul, Republic of Korea. Available at: https://www.kdi.re.kr/kdi_eng/publications/publication_view. jsp?pub_no=14611

Bermúdez-Serrano, I.M., 2020. Challenges and opportunities for the development of an edible insect food industry in Latin America. Journal of Insects as Food and Feed 6: 537-556. https://doi. org/10.3920/JIFF2020.0009

Bryman, A., 2004. Social research methods, $2^{\text {nd }}$ edition. Oxford University Press, New York, NY, USA, 592 pp.

Centro Nacional de Ciencia y Tecnología de Alimentos (CITA), 2019. Proyecto insectos comestibles. CITA, Universidad de Costa Rica, San José, Costa Rica. Available at: http://www.cita.ucr.ac.cr/insectos Cooper, D.R. and Schindler, P.S., 2014. Business research methods. McGraw-Hill Education, New York, NY, USA, 692 pp.
Cortes-Ortiz, J.A., Ruiz, A.T., Morales-Ramos, J.A., Thomas, M., Rojas, M.G., Tomberlin, J.K., Yi, L., Han, R., Giroud, L. and Jullien, R.L., 2016. Insect mass production technologies. In: Dossey, A.T., Morales-Ramos, J. and Rojas, M.G. (eds.) Insects as sustainable food ingredients. Academic Press, San Diego, CA, USA, pp. 153-201. https://doi.org/10.1016/B978-0-12-802856-8.00006-5

Crespi, G., 2010. Nota técnica sobre el sistema nacional de innovación de Costa Rica. Nota técnica IDB-TN-142. Inter-American Development Bank, Washington, DC, USA. Available at: https:// tinyurl.com/28htz4wp

De Sousa, A., Warren, H. and Rekomaa, R., 2018. Bugs are coming soon to your dinner table. Bloomberg, New York, NY, USA. Available at: https://www.bloomberg.com/graphics/2018-insects-as-food/

DESCUBRE, 2020. Qué es Descubre? Available at: http://www. descubre.cr/\#section-descubrimientos

Dossey, A.T., Tatum, J.T. and McGill, W.L., 2016. Modern insect based food industry: current status, insect processing technology and recommendations moving forward. In: Dossey, A.T., MoralesRamos, J. and Rojas, M.G. (eds.) Insects as sustainable food ingredients. Academic Press, San Diego, CA, USA, pp. 113-152. https://doi.org/10.1016/B978-0-12-802856-8.00005-3

Engstrom, A., 2019. Here is the list of entopreneurs around the world. Bugburger, Sweden. Available at: https://www.bugburger.se/foretag/ the-eating-insects-startups-here-is-the-list-of-entopreneursaround-the-world/

FUNDES, 2019. Descubre, productos potenciales y sus cadenas de valor: Cadena de Valor Insectos. Promotora del Comercio Exterior de Costa Rica (PROCOMER), San José, Costa Rica. Available at: http://cita.ucr.ac.cr/sites/default/files/Informe_Cadena_Valor_ Insectos.pdf

Halloran, A., Hanboonsong, Y., Roos, N. and Bruun, S., 2017. Life cycle assessment of cricket farming in north-eastern Thailand. Journal of Cleaner Production 156: 83-94. https://doi.org/10.1016/j. jclepro.2017.04.017

Hanboonsong, Y., Jamjanya, T. and Durst, P, 2013. Six-legged livestock: edible insect farming, collection and marketing in Thailand. Food and Agriculture Organization of the United Nations (FAO), Bangkok, Thailand. Available at: http://www.fao.org/3/i3246e/ i3246e00.htm

International Platform of Insects for Food and Feed (IPIFF), 2019a. Guide on good hygiene practices. IPIFF, Brussels, Belgium. Available at: https://ipiff.org/wp-content/uploads/2019/12/IPIFF-Guide-onGood-Hygiene-Practices.pdf

International Platform of Insects for Food and Feed (IPIFF), 2019b. The European insect sector today, challenges opportunities and regulatory landscape. IPIFF vision paper on the future of the insect sector towards 2030. IPIFF, Brussels, Belgium. Available at: https:// ipiff.org/wp-content/uploads/2019/12/2019IPIFF_VisionPaper_ updated.pdf

Merriam, S. and Tisdell, E., 2016. Qualitative research: a guide to design and implementation, $4^{\text {th }}$ edition. Jossey-Bass, San Francisco, CA, USA, 368 pp. Available at: https://doi.org/10.1177/0741713616671930 
Monge-González, R., 2016. Innovation, productivity, and growth in Costa Rica: challenges and opportunities. InterAmerican Development Bank, Technical Note 920. InterAmerican Development Bank, New York, NY, USA. Available at: https:// publications.iadb.org/publications/english/document/InnovationProductivity-and-Growth-in-Costa-Rica-Challenges-andOpportunities.pdf

Mott, G., 2017. Operational and biological considerations for the commercial production of crickets. In: Van Huis, A. and Tomberlin, J.K. (eds.) Insects as food and feed. Wageningen Academic Publishers, Wageningen, the Netherlands, pp. 270-287. https:// doi.org/10.3920/978-90-8686-849-0

O’Neal, K., 2019. Museo de Insectos UCR: vivo y con buen sabor. Universidad de Costa Rica, San José, Costa Rica. Available at: https:// www.ucr.ac.cr/noticias/2019/10/23/museo-de-insectos-ucr-vivoy-con-buen-sabor.html

Pascucci, S., Dentoni, D. and Mitsopoulos, D., 2015. The perfect storm of business venturing? The case of entomology-based venture creation. Agricultural and Food Economics 3: 3-9. https://doi. org/10.1186/s40100-014-0025-y

Promotora de Comercio Exterior de Costa Rica (PROCOMER), 2019. About us. PROCOMER, San Jose, Costa Rica. Available at: https:// www.procomer.com/investor/general/?lang=en

Ramos-Elorduy, J., Pino, J. and Conconi, M., 2006. Ausencia de una reglamentación y normalización de la explotación y comercialización de insectos comestibles en México. Folia Entomológica Mexicana 45(3): 291-318. https://tinyurl.com/23v9bmf3
Reverberi, M., 2021. The new packaged food products containing insects as an ingredient. Journal of Insects as Food and Feed 7: 901-908. https://doi.org/10.3920/JIFF2020.0111

Rumpold, B. and Schlüter, O., 2013. Potential and challenges of insects as an innovative source for food and feed production. Innovative Food Science and Emerging Technologies 17: 1-11. http://dx.doi. org/10.1016/j.ifset.2012.11.005

Umaña, P., 2020. Mariposas ticas traspasan las fronteras. Universidad de Costa Rica, San José, Costa Rica. Available at: https://www.ucr. ac.cr/noticias/2019/03/20/mariposas-ticas-traspasan-las-fronteras. html

Van Huis, A. and Tomberlin, J.K., 2017. Insects as food and feed: from production to consumption. Wageningen Academic Publishers, Wageningen, the Netherlands, 448 pp. https://doi.org/10.3920/97890-8686-849-0

Van Huis, A., 2020. Insects as food and feed, a new emerging agricultural sector: a review. Journal of Insects as Food and Feed 6: 27-44. https://doi.org/10.3920/JIFF2019.0017

Vantomme, P., 2018. Creating an enabling environment. In: Van Huis, A. and Tomberlin, J. (eds.) Insects as food and feed. Wageningen Academic Publishers, Wageningen, the Netherlands, pp. 381-397. https://doi.org/10.3920/978-90-8686-849-0

World Bank, 2013. Enterprise survey 2010 Costa Rica. World Bank, Washington, DC, USA. Available at: https://microdata.worldbank. org/index.php/catalog/1084/study-description 
